\title{
Factors Affecting Intention to Purchase Green Products in Vietnam
}

\author{
Thi Kim Chi NGUYEN*, Dat Minh NGUYEN**, Van Thien TRINH***, \\ Thi Phuong Diu TRAN****, Tuan Phong CAO*****
}

Received: February 11, 2020 Revised: February 24, 2020 Accepted: March 1, 2020.

\begin{abstract}
The study aims to assess factors affecting intention to purchase green products in Vietnam. The study employs samples from customers who have actually experienced green consumption in Vietnam. The samples were collected by convenient sampling methods. The survey obtained 206 responses with full information. The survey was conducted from October 2019 to January 2020. The measurement scale was a 5-point scale with 1- completely disagree and 5- strongly agree. This study employs factor analysis and structural equation modelling analysis. The results showed that the social and environment sustainability awareness have positive effects on altruism of customers who are interested in green consumption. Altruism also has the same direction on green purchase intention. Besides, the attitude toward buying green and health consciousness affects green purchase intention. At the same time, the altruism and attitude towards buying green products also influence positively on green purchase intention. Besides, the health consciousness positively affects attitude towards buying green products. The results show that the health consciousness has a negative impact on intention to purchase green products. The findings suggest that it is necessary to raise customers' health consciousness, customers' altruism from disseminating knowledge about environmental protection as well as society to enhance the green consumption in Vietnam.
\end{abstract}

Keywords : Green Purchase Intention, Social Sustainability Awarenes, Environment Sustainability Awareness, Health Consciousness

JEL Classification Code : C38, D70, M21

\section{Introduction}

Environmental protection issues have been receiving the attention of society as well as many countries around the world (Ho, Bui, Nguyen, Dao, \& Nguyen, 2020). Vietnam is one of the countries facing environmental protection challenges as well as sustainable development (Nguyen,

*First Author and Corresponding Author. Lecturer, Hanoi University of Business and Technology, Vietnam [Postal Address: 29A/124 Vinh Tuy Street, Hai Ba Trung District, Hanoi, 100000, Vietnam] Tel: +84985004618, Email: nguyenchihubt@gmail.com

**Management Faculty, Ho Chi Minh City University of Law, Vietnam. Email: joe.nguyen1405@gmail.com

***Thanh Ha District People's Committee, Hai Duong Province, Vietnam. Email: thienthhd@yahoo.com

****Academy of Finance, Vietnam.

Email: tranphuongdiu@gmail.com

*****Academy of Social Sciences, Vietnam.

Email: caotuanphong@yahoo.com

(c) Copyright: The Author(s)

This is an Open Access article distributed under the terms of the Creative Commons Attribution Non-Commercial License (http://Creativecommons.org/licenses/by-nc/4.0/) which permits unrestricted noncommercial use, distribution, and reproduction in any medium, permits unrestricted noncommercial use,
provided the original work is properly cited.
Nguyen, Nguyen, \& Vu, 2017). With a population of more than 96.9 million people brings challenges of environmental protection in people's consumption (Worldometer, 2020). With increasing consumption activities leading to an increase in the amount of waste released into the environment (Environment Administration, 2020). Therefore, the implementation / application of green consumption and green procurement policies in Vietnam to encourage sustainable production and consumption is an essential need nowadays.

Excessive use of natural resources has consequences for the environment, so environmental issues have become a global concern (Chen, Huang, Wang, \& Chen, 2020; Kumar, Luthra, Khandelwal, Mehta, Chaudhary, \& Bhatia, 2017). Green consumption is considered a behavior to help protect the environment (Mostafa, 2006), in which green consumers always pay attention to environmental protection, use of pollution reduction products / services, responsible use of natural resources, and recyclable products after use. Consumers are increasingly aware that their consumption activities have caused bad impacts on the environment and they are always inclined to consume green 
in their consumption decisions. (Choi \& Johnson, 2019; Kumar et al., 2017; Mostafa, 2006).

There have been many studies on green consumption behavior as well as customers' intention to purchase green products. In particular, there are studies that show that health consciousness has a positive influence on attitudes and intentions to purchase green products. (Xu, Wang, \& Yu, 2020; Yadav \& Pathak, 2017); Some studies have shown that altruism and environmental and social awareness also positively influence the intention to purchase green products (Choi \& Johnson, 2019; Mostafa, 2006; Panda, Kumar, Jakhar, Luthra, Garza-Reyes, Kazancoglu, \& Nayak, 2020). Among the factors influencing intention to use, studies all use attitudes towards green consumption behavior as in the classic studies on intentions of behavior (Ajzen, 1985; Choi \& Johnson, 2019; Panda et al., 2020; Xu et al., 2020).

In Vietnam, there have been some researchers conducted on green consumption behavior, but the studies focused on exploiting elements in the traditional TPB and TRA models (Hung, Quyen, \& Nhi, 2018). Factors on environmental, health and social awareness have not been evaluated by studies in Vietnam. Therefore, this study assesses the factors that influence consumers' intention to purchase green products in Vietnam.

\section{Literature Review and Hypothesis}

\subsection{Purchasing Intention}

Intention is a person's subjective ability to perform a specific action (Ajzen, 1985, 1991; Ajzen \& Fishbein, 1975) or described as the readiness of customers to purchase and use the product (Ercan \& Matt, 2008; Sousa, Nobre, \& Farhangmehr, 2018). The actual behavior of a person depends on his or her intention or intention to be considered as an important prerequisite for behavior (Ajzen \& Fishbein, 1975), by the consumer decision-making process consists of 5 stages (1) identifying needs, (2) seeking information, (3) evaluating options, (4) purchasing decisions, (5) operating vi after purchase (Kotler \& Armstrong, 2012). When the demand for products / services is large enough, consumers will seek information and will consider evaluating, choosing procurement options and in the process, they will form an intention to buy.

Besides, the intention derived from the definition of Fishbein and Aizen (1975) is understood as the weak power of the intention related to the purchase behavior of customers, so the intention is a good guide for buying behavior of cutomer (Venkatesh, Morris, Davis, \& Davis, 2003). Understanding intention is one of the most authoritative ways to predict customers' decisions, because the larger the intention is in general, the higher the ability to make purchase and use decisions, and the factors of completion. Unpredictable scenes are difficult to predict. In addition, based on a number of theories, customer intent is considered as a basis for guessing future demand (Ajzen \& Fishbein, 1975).

\subsection{Green Consumption Behavior}

Green products are defined as products that are environmentally friendly, non-polluting, and capable of recycling or preserving. Green products can be products made from paper, glass (recyclable or reusable packaging), energy-saving devices, and detergents that must be biodegradable and no pollution (Mostafa, 2006). Green consumption behavior is consumer activities that do not pollute, deplete natural resources and these products are recyclable. (Choi \& Johnson, 2019; McEachern \& McClean, 2002; Mostafa, 2006).

\subsubsection{Social and Environmental Sustainability Awareness and Altruism}

There are many definitions and measures of social sustainability such as health, influence, impartiality; meaning-making, competence (Missimer, Robèrt, \& Broman, 2017). According to McKenzie (2005), definition of sustainable society is: a life-enhancing condition within communities, and a process within communities that can achieve that condition (McKenzie, 2005). Social sustainability brings sustainable benefits to people in the community, including: Income, employment, health, and social activities.

Customer altruism is defined as customer behavior when always taking care of the feelings of others or in other words, taking care of the happiness of others in contexts related to their behavior (Schwartz, 1977). Besides, Panda et al. (2020) thinks that altruism will help customers control their behaviors related to sustainable development; Customers are said to be willing to help others and are always concerned about the environment (Panda et al., 2020). Therefore, customers have good awareness about sustainable development will increase their altruism (Panda et al., 2020; Schwartz, 1977). Therefore, the hypotheses are as follows:

H1: Social sustainability awareness has a positve on altruism

H2: Environmental sustainability awareness has a positve on altruism

\subsubsection{Intention to Purchase Green Products and Altruism}

Altruism is considered in two respects the role that 
social altruism (concern for the welfare of others), and biospheric altruism (a concern for the non-human elements of the environment) play in influencing green behavior (Mostafa, 2006). And when customers are altruistic, they will be more aware of the harmful effects of the environment. From there, they will take actions to protect the environment as well as green consumer behavior. Therefore, the hypotheses are as follows:

H3: Altruism has a positive impact on intetion to purchase green products

\subsubsection{Health Consciousness}

Health consciousness is the customer care about protecting their health in daily activities (Xu et al., 2020; Yadav \& Pathak, 2017). Health factors are always mentioned when customers intend to purchase behavior $(\mathrm{Xu}$ et al., 2020), For example, choosing organic, green products. In recent years, customers have had positive attitudes about green consumption (Xu et al., 2020; Yadav \& Pathak, 2017). At the same time,the health consciousness formed a positive impact on attitude toward buying green. Therefore, the hypotheses are as follows:

H4: Health consciousness has a postitive impact on attitude toward buying green

H5: Health consciousness has a postitive impact on intention to purchase green products

\subsubsection{Attitude toward Buying Green and Intention to Purchase Green Products}

Consumer behavior is the customer's evaluation of positive or negative implications of applying a product / service (Ajzen \& Fishbein, 1975; Nguyen, Nguyen, Dang, \& Nguyen, 2016; Nguyen, Nguyen, \& Vo, 2019; Phan, Nguyen, \& Bui, 2019). Customers who have a positive attitude about the service will increase their intention to use the service (Davis, 1989; Xu et al., 2020). Therefore, the hypotheses are as follows:

H6: Attitude toward buying green has a positive impact on intention to purchase green products.

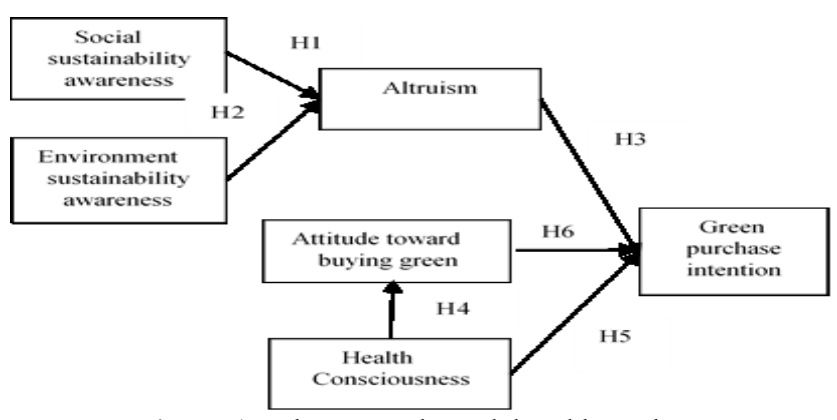

Figure 1 : The research model and hypotheses

\section{Research Method}

\subsection{Research Design}

The measurement questionnaire for each factor in the model is referenced from previous studies (Panda et al., 2020; Yadav \& Pathak, 2017). The survey period is from October 2019 to January 2020. The research scale used is a 5-point scale with 1- completely disagree and 5- strongly agree (see Table 1).

Table 1: The survey

\begin{tabular}{|c|c|c|}
\hline Items & Contents & References \\
\hline \multicolumn{3}{|c|}{ Social sustainability awareness } \\
\hline \multicolumn{2}{|c|}{$\begin{array}{l}\text { Always believe in the sustainable } \\
\text { development of society }\end{array}$} & \multirow{5}{*}{$\begin{array}{l}\text { Panda (2019); Stocki } \\
\text { gt et al. (2018) }\end{array}$} \\
\hline \multicolumn{2}{|c|}{ Always aim for safe and healthy activities } & \\
\hline \multicolumn{2}{|c|}{$\begin{array}{l}\text { Regular participation and community } \\
\text { development activities }\end{array}$} & \\
\hline \multicolumn{2}{|c|}{ Always take positive action to community } & \\
\hline \multicolumn{2}{|c|}{ Work for the common meaning of society } & \\
\hline \multicolumn{3}{|c|}{ Environment sustainability awareness } \\
\hline \multicolumn{2}{|c|}{$\begin{array}{l}\text { You are well aware of climate change / } \\
\text { environment }\end{array}$} & \multirow{6}{*}{ Panda (2019) } \\
\hline & $\begin{array}{l}\text { tection issues are } \\
\text { ly urgent }\end{array}$ & \\
\hline You th & $\begin{array}{l}\text { nmental protection is } \\
\text { onsibility }\end{array}$ & \\
\hline & $\begin{array}{l}\text { thers understand } \\
\text { ntal issues }\end{array}$ & \\
\hline You al & tect the environment & \\
\hline \multicolumn{2}{|c|}{$\begin{array}{l}\text { You realize that environmental protection } \\
\text { associations need to work better }\end{array}$} & \\
\hline \multicolumn{3}{|c|}{ Altruism } \\
\hline \multicolumn{2}{|c|}{$\begin{array}{l}\text { You control your consumption behavior } \\
\text { related to the environment }\end{array}$} & \multirow{6}{*}{ Panda (2019) } \\
\hline \multicolumn{2}{|c|}{$\begin{array}{l}\text { You always act to save energy, reduce your } \\
\text { electricity / water bill }\end{array}$} & \\
\hline You are & $\begin{array}{l}\text { o help others in social } \\
\text { ters }\end{array}$ & \\
\hline \multicolumn{2}{|c|}{$\begin{array}{l}\text { You think that green consumption will help } \\
\text { future generations }\end{array}$} & \\
\hline \multicolumn{2}{|c|}{$\begin{array}{l}\text { You feel proud when you consume green } \\
\text { products }\end{array}$} & \\
\hline \multicolumn{2}{|c|}{ You always care about the environment } & \\
\hline \multicolumn{3}{|c|}{ Health Consciousness } \\
\hline You & healthy products & Yadav \& Pathak (20 \\
\hline
\end{tabular}




\begin{tabular}{|c|c|c|}
\hline Items & Contents & References \\
\hline \multicolumn{2}{|c|}{$\begin{array}{l}\text { You think you are a health conscious } \\
\text { consumer }\end{array}$} & \multirow[t]{2}{*}{ 16a) } \\
\hline \multicolumn{2}{|c|}{$\begin{array}{l}\text { You always think about health issues in your } \\
\text { daily activities }\end{array}$} & \\
\hline \multicolumn{3}{|c|}{ Attitude toward buying green } \\
\hline \multicolumn{2}{|c|}{ You are interested in buying green products } & \multirow{4}{*}{ Panda (2019) } \\
\hline You $\mathrm{f}$ & $\begin{array}{l}\text { en products a smart } \\
\text { ice }\end{array}$ & \\
\hline & duct a good idea & \\
\hline & $\begin{array}{l}\text { reen products an } \\
\text { ng idea }\end{array}$ & \\
\hline \multicolumn{3}{|c|}{ Green purchase intention } \\
\hline \multicolumn{2}{|c|}{$\begin{array}{l}\text { You will buy green products in the near } \\
\text { future }\end{array}$} & \multirow{5}{*}{ Panda (2019) } \\
\hline You & products if needed & \\
\hline \multicolumn{2}{|c|}{ You plan to buy green products in the future } & \\
\hline \multicolumn{2}{|c|}{ You try to buy green products in the future } & \\
\hline You a & y for green products & \\
\hline
\end{tabular}

\subsection{Sampling and Data}

The overall of the study is determined to be customers who have acted green consumption in Vietnam. Research samples were collected by convenient sampling methods. The official survey results obtained 206 questionares. This sample size also ensures reliability according to most sampling rules (Tabachnick \& Fidell, 2006).

\subsection{Data Analysis Method}

Research data were analyzed using multivariate analysis methods. Firstly, the factors in the research model are tested reliability through Cronbach Alpha coefficient greater than 0.6 (Hair et al., 2006) and the Corrected Item-Total Correlation is greater than 0.3 (Nunnally \& Bernstein, 1994). Factor affirmation analysis (CFA) is used to evaluate convergent and discriminant validity. Factors loading greater than 0.5 in each factor are considered to have evaluate convergent and the square root of the variance greater than the correlation between research concepts are concepts with discriminant validity (Hair et al., 2006). Next, we use the structure model (SEM) at the $5 \%$ significance level to find out the factors that influence the intention to purchase green products. The CFA, critical and SEM models are reliable when the Chi - square / df is less than 3; The value of CFI, TLI, IFI is greater than 0.9; RMSEA is less than 0.05 (Hair et al., 2006; Hooper, Coughlan, \& Mullen, 2008).

\section{Results}

\subsection{Descriptive Statistics}

Collecting results on 206 customers, of which men accounted for less than women with $47.1 \%$; women accounted for $52.9 \%$. Regarding the education level, the majority of customers surveyed is University (141 people accounting for $68.4 \%$ ), followed by the group with university education with 62 people accounting for $30.1 \%$; The last is the group with high school education with 3 people accounting for $1.5 \%$. Income of main customers is less than 10 million VND (104 people account for 50.5\%), followed by the group of 10 to 15 million ( 74 people accounting for $35.9 \%$ ), the last is the group of over 15 million people with 28 people accounting for $13.6 \%$ (see Table 2).

Table 2: Descriptive Statistics

\begin{tabular}{|c|c|c|c|}
\hline & & Frequency & Percent \\
\hline \multirow{2}{*}{ Gender } & Female & 109 & 52.9 \\
\hline & Male & 97 & 47.1 \\
\hline \multirow{3}{*}{ Education } & High school & 3 & 1.5 \\
\hline & $\begin{array}{l}\text { College / } \\
\text { University }\end{array}$ & 141 & 68.4 \\
\hline & Graduate & 62 & 30.1 \\
\hline \multirow{4}{*}{ Income } & $\begin{array}{l}\text { Less than } 10 \\
\text { million }\end{array}$ & 104 & 50.5 \\
\hline & $\begin{array}{l}\text { From } 10-15 \\
\text { million }\end{array}$ & 74 & 35.9 \\
\hline & $\begin{array}{l}\text { Over 15 } \\
\text { million }\end{array}$ & 28 & 13.6 \\
\hline & Total & 206 & $100 \%$ \\
\hline
\end{tabular}

\subsection{Reliability Test}

The items in each factor were included in the analysis of scale reliability through two indicators of Cronbach's Alpha coefficient and the Corrected Item-Total Correlation. The results show that the Cronbach's Alpha coefficients of the factors are all greater than 0.6 and the Corrected Item-Total Correlation of itmes are greater than 0.3. Therefore, all factors gain confidence when measuring through the given items (see Table 3).

After the factors that ensure reliability when measuring through the items given. Factors as well as items are included in CFA. The CFA results indicate that the items: SS5, ES2, E5, AL3 and AL4 are removed because the factor loading is less than 0.5. Chi-square / $\mathrm{df}=2,218$ is less than 5 , CFI $=0.927$; TLI $=0.908 ; \mathrm{IFI}=0.928$ are greater than 
0.9 , RMSEA $=0.077$ is less than 0.08 . This shows that the theoretical model is compatible with real data. The factors loading of each items are greater than 0.5 , so it is possible to see the model of evaluate convergent.

Table 3: Reliability test

\begin{tabular}{|c|c|c|}
\hline & Cronbach's Alpha & $\begin{array}{c}\text { Corrected Item- } \\
\text { Total Correlation }\end{array}$ \\
\hline SS & .817 & .540 \\
\hline ES & .862 & .555 \\
\hline AL & .861 & .553 \\
\hline HC & .878 & .729 \\
\hline ATT & .901 & .693 \\
\hline INT & .884 & .633 \\
\hline
\end{tabular}

Table 4: Composite reliability and Average Variance Extracted

\begin{tabular}{|c|c|c|c|c|}
\hline \multicolumn{3}{|c|}{ Factor } & $\begin{array}{l}\text { Composite } \\
\text { reliability }\end{array}$ & AVE \\
\hline SS1 & $<---$ & SS & \multirow{4}{*}{0.784354} & \multirow{4}{*}{0.694328} \\
\hline $\mathrm{SS} 2$ & $<---$ & SS & & \\
\hline SS3 & $<---$ & SS & & \\
\hline SS4 & $<---$ & SS & & \\
\hline $\mathrm{HC} 1$ & $<---$ & $\mathrm{HC}$ & \multirow{3}{*}{0.882806} & \multirow{3}{*}{0.84582} \\
\hline $\mathrm{HC} 2$ & $<---$ & $\mathrm{HC}$ & & \\
\hline $\mathrm{HC} 3$ & $<---$ & $\mathrm{HC}$ & & \\
\hline ES6 & $<---$ & ES & \multirow{4}{*}{0.81299} & \multirow{4}{*}{0.72274} \\
\hline ES1 & $<---$ & ES & & \\
\hline ES3 & $<---$ & ES & & \\
\hline ES4 & $<---$ & ES & & \\
\hline INT1 & $<--$ & INT & \multirow{5}{*}{0.888303} & \multirow{5}{*}{0.784305} \\
\hline INT2 & $<---$ & INT & & \\
\hline INT3 & $<--$ & INT & & \\
\hline INT4 & $<---$ & INT & & \\
\hline INT5 & $<---$ & INT & & \\
\hline ATT1 & $<---$ & ATT & \multirow{3}{*}{0.894368} & \multirow{3}{*}{0.859626} \\
\hline ATT2 & $<--$ & ATT & & \\
\hline ATT3 & $<---$ & ATT & & \\
\hline AL1 & $<---$ & $\mathrm{AL}$ & \multirow{5}{*}{0.857888} & \multirow{5}{*}{0.741366} \\
\hline AL2 & $<--$ & $\mathrm{AL}$ & & \\
\hline AL5 & $<--$ & $\mathrm{AL}$ & & \\
\hline AL6 & $<---$ & $\mathrm{AL}$ & & \\
\hline AL7 & $<---$ & $\mathrm{AL}$ & & \\
\hline
\end{tabular}

The results of the composite reliability analysis and the average extracted variance (AVE) show that the factors are the scales with load factor greater than 0.5 , reaching the convergent validity. The the composite reliability above 0.7 and the average extracted variance are greater than $50 \%$. This shows that the factor scales in the formal sample have achieved the necessary reliability (see Table 4).

For square root of AVE, all factors in the model are greater than the correlation coefficients between the variables that indicate the factors that achieve the discriminant validity (see Table 5).

Table 5: Discriminant validity

\begin{tabular}{|c|c|c|c|c|c|}
\hline & HC & ATT & INT & SS & ES \\
\hline HC & 0.920 & & & & \\
\hline ATT & 0.788 & 0.927 & & & \\
\hline INT & 0.696 & 0.836 & 0.886 & & \\
\hline SS & 0.809 & 0.604 & 0.722 & 0.833 & \\
\hline ES & 0.772 & 0.834 & 0.779 & 0.805 & 0.850 \\
\hline AL & 0.838 & 0.828 & 0.873 & 0.801 & 0.826 \\
\hline
\end{tabular}

\subsection{Structural Equation Modeling}

With the factors of reliability, evaluate convergent and discriminant validity will be included in the analysis of the SEM model. The results of SEM model analysis are reliable with Chi-quare $/ \mathrm{df}=2.238 \mathrm{CFI}=925 ; \mathrm{TLI}=907 ; \mathrm{IFI}=926$; RMSEA $=0.078$. SEM model results are obtained as follows:

Through SEM model coefficients and p-value at 5\% significance level indicate that SUS and ES factors have positive effects on Altruism ( $\beta$ SUS $=.205 ; \beta E S=.761$ and $p$ value less than .05), the hypotheses $\mathrm{H} 1$ and $\mathrm{H} 2$ are accepted.

The awareness of a sustainable society and a sustainable environment that has a positive effect on altruism indicates that customers with a high social awareness will increase their altruism. Customers perceive socially as well as the environment as customers who care about others as well as the well-being of others related to their consumption behaviors. (Panda et al., 2020; Schwartz, 1977).

Altruism has a positive impact on green purchase intention $\left(\beta_{\mathrm{AL}}=.575\right.$ and $\mathrm{p}$-value less than 0.05$)$ so the hypothesis $\mathrm{H} 3$ is accepted. When customers have altruism, they will care about the health of the community and take actions to help protect the environment (Mostafa, 2006; Xu et al., 2020). Therefore, they always care as well as learn about environmental protection products. Therefore, when there are green products or services that help protect the environment, altruistic customers are always aiming for stronger green consumption.

Health consciousness has a positive impact on attitude of toward buying green $\left(\beta_{\mathrm{HC}}=.284\right.$ and p-value less than .05), the hypothesis $\mathrm{H} 4$ is accepted. Health 
consciousness helps customers have better attitudes about green consumption behavior. With the awareness of using healthy products / services, customers always appreciate the use of green products. (Xu et al., 2020). With positive effects from using green products, customers have good attitude towards green consumption. Customers always believe that green consumption is a common trend activity in protecting health as well as the environment.

Attitude toward buying has positive impact on green purchase intention $\left(\beta_{\mathrm{ATT}}=.553 \mathrm{p}\right.$-value less than .05$)$ so the hypothesis $\mathrm{H} 6$ is accepted. This result shows a positive and close relationship on the influence of attitudes on green consumption on green consumption intent. Customers with a positive attitude to green consumption behavior also intend to use it more (Ajzen \& Fishbein, 1975; Panda et al., 2020; Xu et al., 2020). However, the hypothesis H5 on the influence of health consciousness on the intention of green consumption is in the opposite relationship $\left(\beta_{\mathrm{HC}}=-.185\right.$ and $\mathrm{p}$-value less than .05). This result accepts the relationship between health awareness and intention to consume green (see Figure 2).

However, the negative impact of health consciousness on Green purchase intention shows that customers who have a good sense of their health despite having a good attitude towards using green products / services have reduced their intention to purchase green products. This result raises doubts about customers' confidence in green products marketed. Customers who care a lot about health prefer to use green products with clear roots and that they can control themselves. Products floating in the market of unknown origin, the group of customers interested in health tends to reduce green purchase intention.

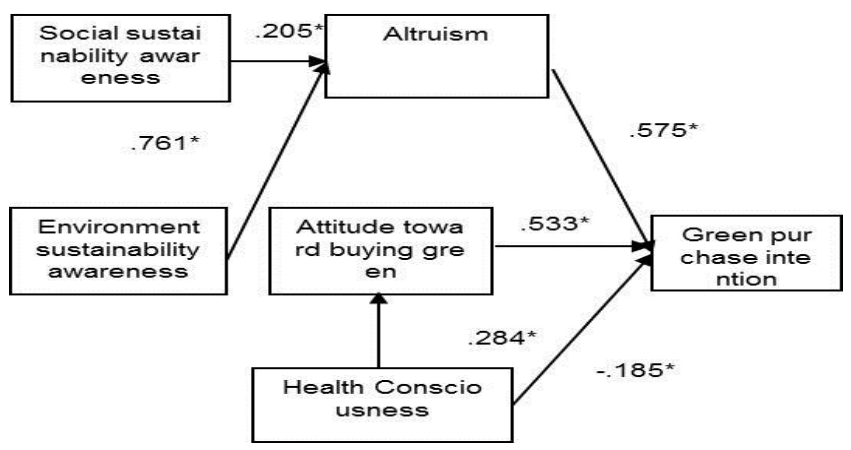

Figure 2: Result of SEM

\section{Conclusion}

With 206 observation samples, based on the results of SEM model analysis, it showed that the factors of Social sustainability awareness, Environment sustainability awareness have positive effects on altruism of customers who are interested in green consumption behavior. At the same time, Altruism also has the same direction on green purchase intention. Besides, the attitude toward buying green and health consciousness affects green purchase intention. The research results show that to enhance the green procurement intention, it is necessary to raise customers' health consciousness, raise customers' altruism from disseminating knowledge about environmental protection as well as society. Dissemination forms of knowledge about protecting their health as well as those around them will help customers have a positive attitude toward buying green products.

\section{Reference}

Ajzen, I. (1985). From Intentions to Actions: A Theory of Planned Behavior. In J. Kuhl \& J. Beckmann (Eds.), Action Control: From Cognition to Behavior (pp. 11-39). New York, NY: Springer. https://doi.org/10.1007/978-3-642-69746-3_2

Ajzen, I. (1991). The theory of planned behavior. Organizational Behavior and Human Decision Processes, 50(2), 179-211. https://doi.org/10.1016/0749-5978(91)90020-T

Ajzen, I., \& Fishbein, M. (1975). A Bayesian analysis of attribution processes. Psychological Bulletin, 82(2), 261-277. https://doi.org/10.1037/h0076477

Chen, Y.-S., Huang, A.-F., Wang, T.-Y., \& Chen, Y.-R. (2020). Greenwash and green purchase behaviour: The mediation of green brand image and green brand loyalty. Total Quality Management \& Business Excellence, 31(1-2), 194-209. https://doi.org/10.1080/14783363.2018.1426450

Choi, D., \& Johnson, K. K. P. (2019). Influences of environmental and hedonic motivations on intention to purchase green products: An extension of the theory of planned behavior. Sustainable Production and Consumption, 18, 145-155. https://doi.org/10.1016/j.spc.2019.02.001

Davis, F. D. (1989). Perceived Usefulness, Perceived Ease of Use, and User Acceptance of Information Technology. MIS Quarterly, 13(3), 319-340. JSTOR. https://doi.org/10.2307/249008

Environment Administration. (2020). Green consumption is geared towards sustainable development. Retrieved from http://tapchimoitruong.vn/pages/article.aspx?item=Ti\% $\%$ 3\%A Au-d\%C3\%B9ng-xanh-h\%C6\%B0\%E1\%BB\%9Bng$\%$ C4\%91\%E1\%BA\%BFn-ph\%C3\%A1t-tri\%E1\%BB\%83nb\%E1\%BB\%81n-v\%E1\%BB\%AFng-40643

Ercan, T., \& Matt, E. (2008). Qualifying purchase intentions using queueing theory. Journal of Applied Quantitative Methods, 3(2), 167-178.

Hair, J. F., Black, W. C., Babin, B. J., Anderson, R. E., \& Tatham, R. L. (2006). Multivariate data analysis (6th Ed.) Journal of Abnormal Psychology, 87, 49-74.

Ho, T. N., Bui, A. T., Nguyen, V. D., Dao, T. K., \& Nguyen, N. D. (2020). Analyzing the impact of FDI and urbanization on CO2 emission in Vietnam. International Journal of Business and Globalisation, 12, 1-19.

Hooper, D., Coughlan, J., \& Mullen, M. R. (2008). Structural Equation Modelling: Guidelines for Determining Model Fit. 
Electronic Journal of Business Research Methods, 6, 53-60.

Hung, H. T., Quyen, H. T. T., \& Nhi, H. T. (2018). Factors affecting consumer behavior green consumers in Hue city. Journal of Science, 127(5A), 199-212.

Kumar, A., Luthra, S., Khandelwal, D. K., Mehta, R., Chaudhary, N., \& Bhatia, S. (2017). Measuring and improving customer retention at authorised automobile workshops after free services. Journal of Retailing and Consumer Services, 39, 93102. https://doi.org/10.1016/j.jretconser.2017.07.007

McEachern, M. G., \& McClean, P. (2002). Organic purchasing motivations and attitudes: Are they ethical? International Journal of Consumer Studies, 26(2), 85-92. https://doi.org/10.1046/j.1470-6431.2002.00199.x

McKenzie, D. J. (2005). Measuring inequality with asset indicators. Journal of Population Economics, 18(2), 229-260. https://doi.org/10.1007/s00148-005-0224-7

Missimer, M., Robèrt, K.-H., \& Broman, G. (2017). A strategic approach to social sustainability - Part 2: A principle-based definition. Journal of Cleaner Production, 140, 42-52. https://doi.org/10.1016/j.jclepro.2016.04.059

Mostafa, M. M. (2006). Antecedents of Egyptian Consumers' Green Purchase Intentions. Journal of International Consumer Marketing, 19(2), 97-126. https://doi.org/10.1300/J046v19n02_06

Nguyen, N. D., Nguyen, T. H., Dang, B. N., \& Nguyen, V. D. (2016). Factors affecting consumer's buying behaviour toward tourism products on internet: An empirical investigation of Hanoi Consumers. Journal of Economics and Development, 245, 77-88.

Nguyen, P. N. D., Nguyen, V. T., \& Vo, N. N. T. (2019). Key Determinants of Repurchase Intention toward Organic Cosmetics. Journal of Asian Finance, Economics and Business, 6(3), 205-214. https://doi.org/10.13106/jafeb.2019.vol6.no3.205

Nguyen, V. D., Nguyen, N. D., Nguyen, T. H. A., \& Vu, H. P. (2017). Impact of fdi and co2 emission on economic growth: Evidence of some asian countries. External Economics, 91, 59-66.

Nunnally, J. C., \& Bernstein, I. H. (1994). Psychometric theory. New York, NY: McGraw-Hill.

Panda, T. K., Kumar, A., Jakhar, S., Luthra, S., Garza-Reyes, J. A.,
Kazancoglu, I., \& Nayak, S. S. (2020). Social and environmental sustainability model on consumers' altruism, green purchase intention, green brand loyalty and evangelism. Journal of Cleaner Production, 243, 118575. https://doi.org/10.1016/j.jclepro.2019.118575

Phan, D. T. T., Nguyen, T. T. H., \& Bui, T. A. (2019). Going beyond Border? Intention to Use International Bank Cards in Vietnam. Journal of Asian Finance, Economics and Business, 6(3), 315-325.

https://doi.org/10.13106/jafeb.2019.vol6.no3.315

Schwartz, S. H. (1977). Normative Influences on Altruism11This work was supported by NSF Grant SOC 72-05417. In L. Berkowitz (Ed.), Advances in Experimental Social Psychology (Vol. 10, pp. 221-279). Cambridge, MA: Academic Press. https://doi.org/10.1016/S0065-2601(08)60358-5

Sousa, A., Nobre, H., \& Farhangmehr, M. (2018). An Empirical Study about the Influence of Country Personality and Product Involvement on Consumer's Purchase and Visit Intentions. Journal of Asian Finance, Economics and Business, 5(3), 6572. https://doi.org/10.13106/jafeb.2018.vol5.no3.65

Tabachnick, B. G., \& Fidell, L. S. (2006). Multivariate analysis of grouped data. In Invited workshop presented to the meeting of the Western Psychological Association, Palm Springs, CA.

Venkatesh, V., Morris, M. G., Davis, G. B., \& Davis, F. D. (2003). User Acceptance of Information Technology: Toward a Unified View. MIS Quarterly, 27(3), 425-478. JSTOR. https://doi.org/10.2307/30036540

Worldometer. (2020). Vietnam Population. Retrieved January 10, 2020, from: https://www.worldometers.info/worldpopulation/vietnam-population/

$\mathrm{Xu}$, X., Wang, S., \& Yu, Y. (2020). Consumer's intention to purchase green furniture: Do health consciousness and environmental awareness matter? Science of the Total Environment, 704, 135275. https://doi.org/10.1016/j.scitotenv.2019.135275

Yadav, R., \& Pathak, G. S. (2017). Determinants of Consumers' Green Purchase Behavior in a Developing Nation: Applying and Extending the Theory of Planned Behavior. Ecological Economics, 134, 114-122. https://doi.org/10.1016/j.ecolecon.2016.12.019 